\title{
DIFFERENT TYPES OF BIOMATERIALS: STRUCTURE AND APPLICATION: A SHORT REVIEW
}

Miljana Z. Rubežić, Aleksandra B. Krstić, Hristina Z. Stanković, Radomir B. Ljupković, Marjan S. Ranđelović, Aleksandra R. Zarubica*

(REVIEW PAPER)

UDC 66.017/.018:615.46

University of Niš, Faculty of Science and Mathematics, Niš, Serbia

Biomaterials are characterized as any material of natural or synthetic origin that comes into contact with the tissue, blood or biological fluids of a patient and which are, due to their exceptional structural characteristics but also potential applications in many branches of industry and medicine (prosthetic, diagnostic, therapeutic, or storage applications, etc.) used to improve the patient's life. Biomaterials which can be found everywhere in nature, both on land and in water, are of particular importance. These are materials based on spider silk, silkworms, corals, shells, fish bones as well as eggshells. The structure of these materials is extremely interesting because of the features such as remarkable physicochemical and mechanical properties that further allow the application in various branches of medicine such as orthopedics, neurology, dentistry, tissue engineering. The application is based on the use of these materials in the form of various implants, biomolecule carriers, wound healing agents, antimicrobial agents, dental fillings because they have an extremely long duration time and there is a minimal need for replacement or repair.
Keywords: corals, eggshell, seashell, silk of silkworm, spider silk

\section{Introduction}

Biomaterials are a group of non-living materials that is of great interest to research today and have potential applications in many industries. Biomaterials are characterized as any substance or the combination of substances other than medicines of synthetic or natural origin, which can be used for any period of time and play the role of enhancing and/or partially or completely replacing a tissue, an organ or a function of the body in order to maintain or improve the quality of life of the individual. It is intended for use in prosthetic, diagnostic, therapeutic or storage applications without adversely affecting the organism and its component. What is also very important for these materials is that they have an extremely long duration time, and can be used for a long period of time without the need for any repair or replacement [1].

These materials are used in various branches of medicine such as orthopedics, neurology, ophthalmology, but also dentistry, tissue engineering, for the manufacture of various implants, carriers for biomolecules etc. [1].

The ability of biomaterials to perform a particular function in a given situation with the appropriate tissue response is called biocompatibility. In addition to biocompatibility for the application of biomaterials, mechanical continuity with the surrounding bone tissue, the non-toxicity of biomaterials or their products during degradation, as well as low cost is important $[2,3]$.

A matrix intended for tissue engineering purposes must support cell adhesion, distribution, growth, and differentiation. In most cases, the matrix needs to be degraded into biocompatible fragments or monomers capable of metabolizing by host cells. However, the degree of degradation should correspond to, or be less than the degree of tissue healing and the development. The balance between the two processes allows for the adequate mechanical and physiological compatibility during the integration of native and/or implanted tissue in vivo [4].

Biomaterial research is one of the most important areas of modern medicine. In recent years, the use of silk-based materials (obtained from spider net, silkworm, goat), seashells, corals, fish skeleton, eggshells as biomaterials has been studied a lot. These biomaterials have been proven to be used as: a wound-healing agent, an organ implant, in dentistry as part of a dental filler, in tissue engineering, as an antimicrobial agent alone or as part of the bandage, for drug release, etc.

\section{Spider silk}

Spider silk fibers have fascinated scientists for years, especially because of their outstanding mechanical properties [5]. The combination of the strength and elasticity gives toughness that cannot be achieved by another natural or synthetic fiber [6]. Also, spider silk is biocompatible, biodegradable and has hypoallergenic properties suitable for biomedical applications $[7,8]$.

\footnotetext{
*Author address: Prof. dr Aleksandra R. Zarubica, Department of Chemistry, Faculty of Science and Matematics, University of Niš, Višegradska 18000 Niš, Serbia

E-mail: zarubica2000@yahoo.com

The manuscript received: December, 05, 2019

Paper accepted: February, 21, 2020.
} 
Spider silk represents a whole class of materials with different properties because a spider can produce several types of silk.

Fiber synthesizing spiders can produce up to 7 different types of fibers that are composed of 1 or 2 spindroins, all of which are encoded by the members of a single gene family [9].

The most important are three types of fibers: MA (Major ampullate) fibers-Tensile fibers, MI (Minor ampullate) fibers, Flagelliform fibers. They are illustrated in Figure 1.

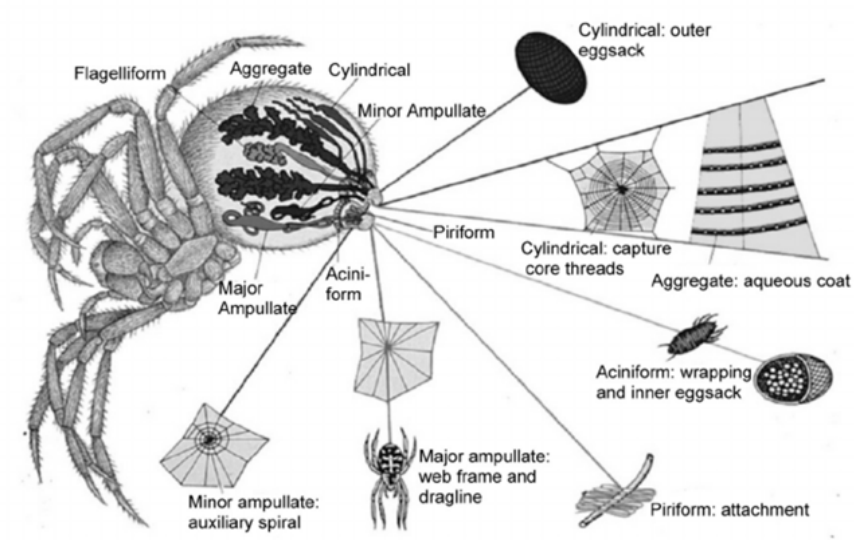

Figure 1.The illustration showing a spider and its glands responsible for producing different types of fibers, as well as the functions of these fibers [10].

Fibers called Major Ampullate (MA), that is, tensile fibers have the best characteristics, making the outer frame a net which also serves as the most important fiber for spider life [11]. Two classes of Major Ampullate spidroins which differ in the proline content and hydrophobicity [12] have been identified in fibers, termed MaSp1 and MaSp2. All Major Ampullate spidroins consist of the nucleus [13].

The nucleus contains various parts with amino acid (rich in glycine and polyalanine) which provide secondary structures that are responsible for the mechanical properties of the fibers [13 - 16]. The end portions of the nucleus play an important role when storing spidroins [17 - 20].

The biotechnological production of spider silk proteins, as well as the development of silk processing techniques, made it possible to use these materials for biomedical purposes such as implant coatings, drug release systems or tissue engineering and much more.
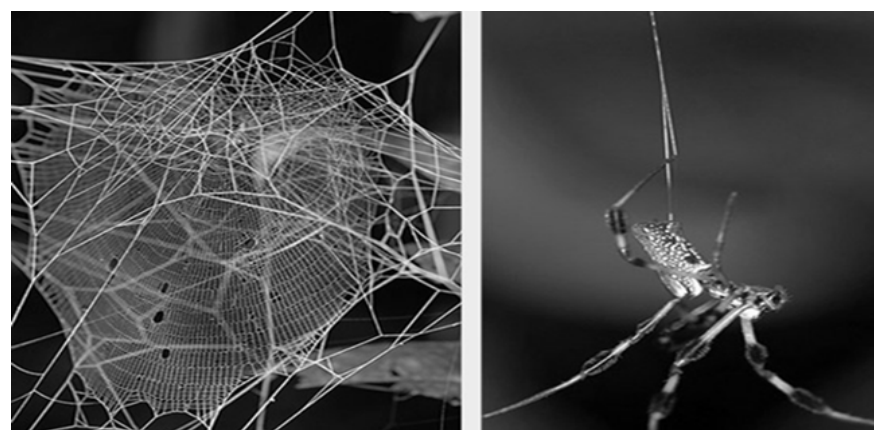

Figure 2. Spider silk in nature [85].

\section{Silk of Silkworm}

Silk fibroin-based biomaterials are most commonly produced from the protein of the domestic silkworm Bombyx mori (Shown in Figure 3. (A)), which is the largest producer of silk fibers. At the end of the larval-shaped phase, after the spinning process, the silkworm creates cocoon-shaped silk fibers (Shown in Figure 3.(B)). The amount of fiber in one cocoon is 600-1500 $\mathrm{m}$ [4].

The cocoon fiber is composed of two protein components, fibroin and sericin (Shown in Figure 3. (B)), originally synthesized in the posterior and middle glands of the silkworm. Fibroin is a major component of the cocoon and forms the filament core, while water-soluble sericin cements fibroin fibers in the cocoon as glue. Silk fibroin (Shown in Figure 3. (C)) is essentially a fibrous and structural protein, characterized by long-term ordered molecular secondary structures formed by heavy $(\mathrm{H})$ and light chain $(\mathrm{L})$, the chains linked via disulfide bonds at the $C$ terminal end; the amino acid composition of fibroin chains is made of 12 repeat domains in the form of clustered oligopeptides Gli-Ala-Gli-Ala-GliSer,[Gli-Ala]nGli-Tir and [Gli-Val]n-Gli-Ala(n), separated with 11 amorphous regions composed of Gli-AlaGli-Ser and Gli-Ala-Gli-Ala-Gli-Ser. The H chain, more abundant than hydrophobic amino acid residues, has a high molecular weight $(\approx 350 \mathrm{kDa})$ and is an essentially amphiphilic exchangeable copolymer block with amorphous regions. The $L$ chain $(M V \approx 26 \mathrm{kDa})$ is more hydrophilic characterized by a higher content of Glu and Asp residues [4].

The structural hierarchy of hydrophobic and copolymer blocks in Bombyx mori silk fibroin demonstrates a unique selfassembly capability that enables substrates with outstanding physico-chemical, biological and mechanical properties to be made, making silk fibroin a promising and first choice material suitable for innovative biotechnological applications [4].
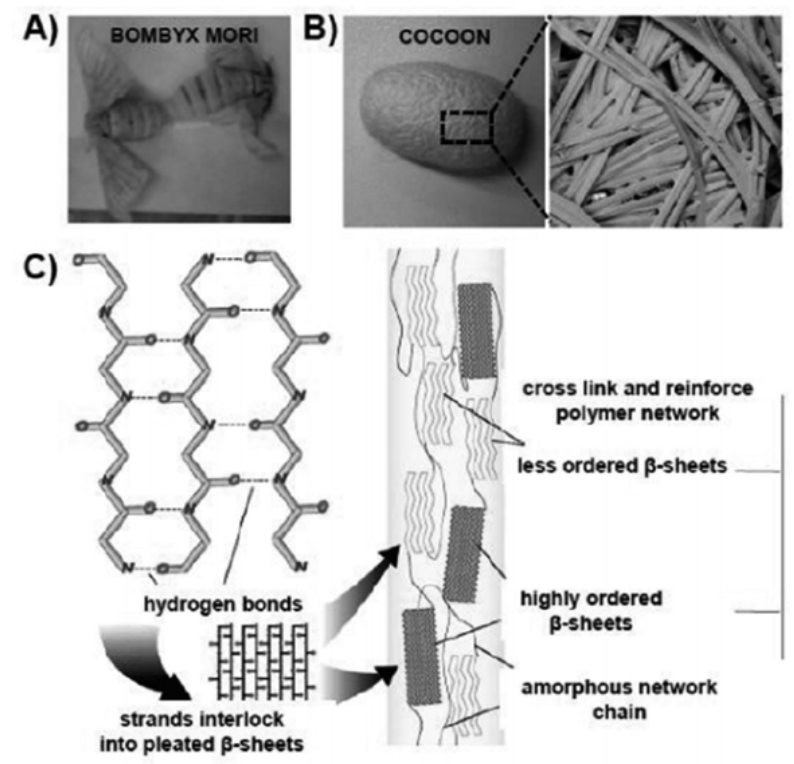

Figure 3. A) House silkworm Bombyx mori (Mulberry species); B) Bombyx cocoon composition: fibroin fiber core coated with sericin layers; Scheme of fibroin structure and amino acid sequence [4]. 


\section{Eggshell}

Eggshell is a commonly used biomaterial in nature. It is a material often used to treat potential waste because it is a by-product of the food industry and is considered as waste after the egg production. A fresh eggshell consists of a typical three-layered form; the foamy cuticle on the outer surface resembles ceramics; a spongy middle layer; the inner layer consists of lamellar layers (Shown in Figure 4.). Together with the membrane, the eggshell represents $11 \%$ of the total egg weight, and its major component is calcite $\mathrm{CaCO}_{3}(94 \%)$. The remaining components include $\mathrm{MgCO}_{3}(1 \%), \mathrm{Ca}_{3}\left(\mathrm{PO}_{4}\right)_{2}(1 \%)$, and organic matter (primarily insoluble proteins) (4\%) [21]. It is characterized by an unique microstructure $[22,23]$ and has very interesting application potential $[24,25]$. Despite its abundant application, the material is not being used adequately in the industry.

Specific areas involving its use are as follows: fertilizer and soil improver [26], as a heavy metal sorbent [27,28] or dye [29], as a source of calcium for the synthesis of hydroxyapatite which is later used in tissue engineering [30] , as a source of calcium oxide for $\mathrm{CO}_{2}$ sorption [31], or as a precursor for composite materials further used in various fields [32,33]. If the eggshell biomaterial is on the nano-scale, its application potential is expanded [34,35].

The industrial waste of the eggshell also contains a membrane of the shell and is suitable for a wide vari- ety of applications [36]. The treatment of the eggshell by various techniques can further expand its range of application. One such approach is mechanochemical $[37,38]$.

As mentioned above, the major component of the eggshell is calcite with a trigonal crystalline structure. According to the literature, they are prone to phase transformation into orthorhombic aragonite and vice versa. A mechanochemical study of pure calcite has shown that it converts to orthorhombic aragonite if appropriate milling conditions are applied [39-41], mainly because it is stable at high pressures and has a higher density $\left(\left(\right.\right.$ calcite $=2,71 \mathrm{~g} \mathrm{~cm}^{-1}$, paragonite $\left.=2,94 \mathrm{~g} \mathrm{~cm}^{-1}\right)$. Total conversion from one phase to another was not observed, and the equilibrium ratio between calcite and aragonite was about 30:70. A similar result was obtained when the process started with pure aragonite [39]. However, when the milling process was not as intense, no transformation was observed [42]. The eggshell material is different from pure calcite and, as documented in several papers, some authors have noted the transformation, while some have not. The presence of an eggshell membrane in the system can also affect this transformation.

Calcification of the eggshell is considered to be one of the fastest known processes of biomineralization, and the largest part of the mineral contained in the eggshell is calcite, a needle-like hydroxyapatite in small quantities which is located in the inner cuticle [43].
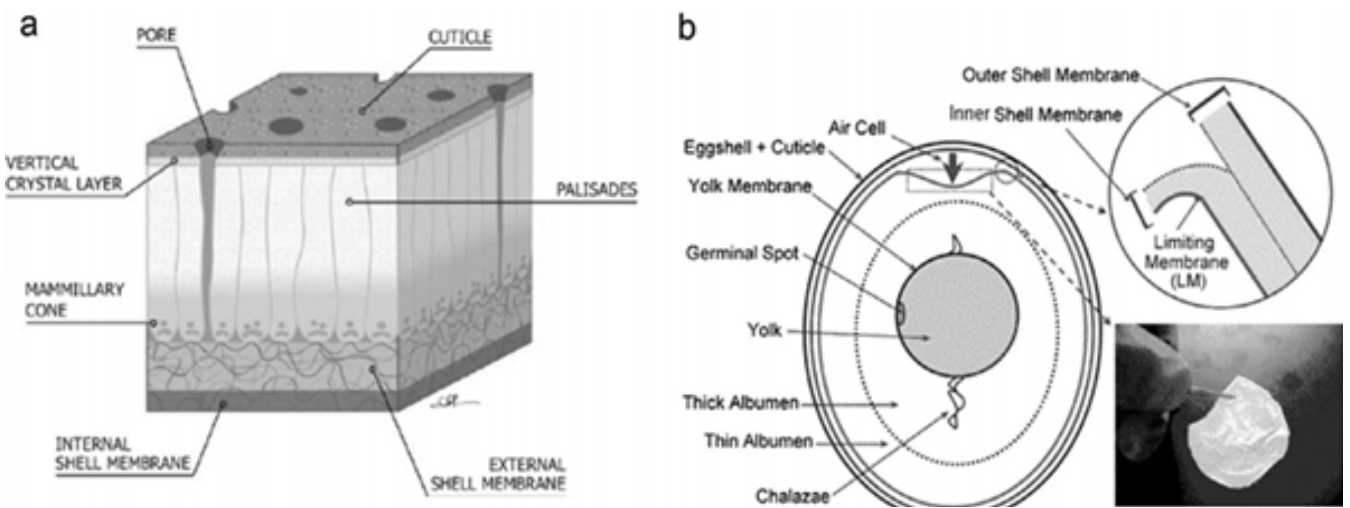

Figure 4. a) Artistic representation of the cross-section view of an eggshell; b) The structure of the egg (upper inset: substructure of the eggshell membrane; lower inset: a photograph of the inner eggshell membrane) [44].

Seashell

Mollusk shells are fascinating organic compounds with powerful mechanical properties. These shells are mainly made of crystalline polymorphs of calcite and aragonite (Shown in Figure 5.). Fleischli et al. [45] think that, due to their structural alignment and nacres called as mother of pearl, these natural materials exhibit outstanding properties and this is considered as a standard for the properties of seashells. Barthelat et al. [46] investigated the nacres and found that it is an iridescent material and forms the inner layers of the shells. Chateigner [47] suggested that the nacres have a good lamellar structure and a better microstructure than any other marine shell. Barthelat [48] stated that shells ex- hibit better rigidity, strength, and hardness due to their microstructure. Falade et al. [49] examined the suitability of palm kernel shells as fillers for structural and non structural purposes. Mollusk shells are natural composites biologically engineered on nanoparticles. Kaplan et al. [50] have suggested that this property can provide toughness and can be a profitable property for the development of biocomposites. 


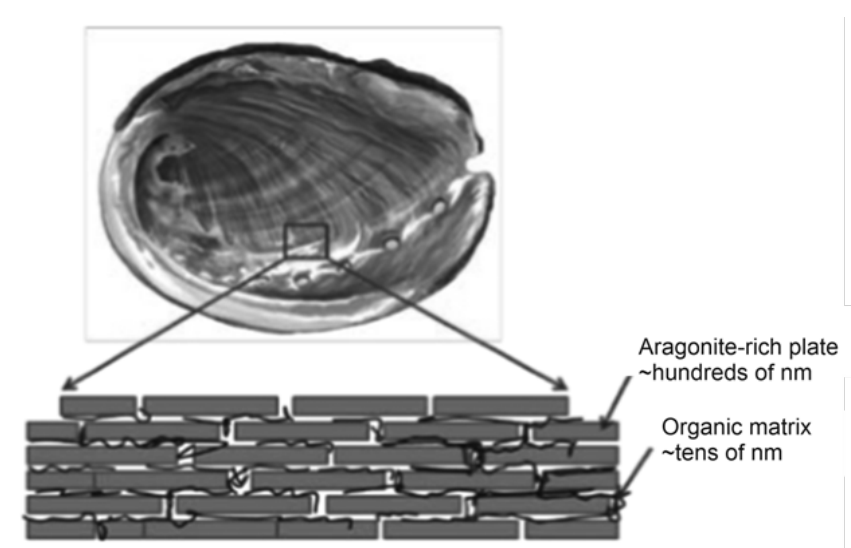

Figure 5. Schematic of nacre with the brick-and-mortar like structure in which hard aragonite-rich plates are glued together with the soft organic matrix to form tiles. [51].

There is a number of shells, some of which are: a short-necked shell, a bloodsucker, and a hard shell. The short-necked shellfish (Paphia undulata) is a marine organism that has a fast-growing rate but a short life span $[52,53]$. Anadara granosa or known as bloodsucker is usually found in the intertidal mud, and it has a shell that is of white color [52,54]. As for the hard shell, which is also known as Meretrik lirata, it has a thin hard shell and can be found near coastal areas [55].

The world production of mollusks in 2015. alone is estimated at 16 million tonnes. However,this led to the creation of copious amounts of the sea shell waste. The seashell waste is mainly used for low-value recycling, such as in the craft industry for the production of decorative materials like key chains and as a recycling medium for the road construction, as well as brick for construction $[56,57]$.

Thus, seashells are underutilized and they are still considered waste. Due to a costly disposal process such as incineration [58], the seashell waste is generally disposed of in landfills without any subsequent treatment.

Landfills often cause an unpleasant view of the environment and give off an unpleasant odor. To reduce the negative environmental impacts, researchers are studying the transformation of the seashell waste into valuable products such as biomaterials. Biomaterials are synthetic or natural materials that are suitable for the manufacture of artificial organs and dentures or bone or tissue replacement. In fact, seashells consist of calcium carbonate $\left(\mathrm{CaCO}_{3}\right)$ of over $95 \%$ by weight [59]. It has previously been used as a source of calcium for the synthesis of hydroxyapatite (HAp) $[60,61]$. With the chemical formula $\mathrm{Ca}_{10}\left(\mathrm{PO}_{4}\right)_{6}(\mathrm{OH})_{2}$, HAp is widely used in biomedical applications, mainly as a substitute for bone, regeneration and dental renewable materials due to their biocompatibility, biosorption, and bioactivity. HAP is reminiscent of natural bone and has the ability to allow chemical bonding with the bone structure [62].

\section{Corals}

Natural coral has been primarily used in tissue en- gineering as a replacement for human bones for more than 10 years, but also in various fields of medicine: orthopedic, craniofacial, dental and neurosurgery. The advantage of using bones that have coral in their composition is that the material is extremely stable and easily decalcified. Natural coral is characterized by a pore size of $150-200 \mu \mathrm{m}$ and a porosity of $36 \%$ [63].

Various types of corals of the genus Porites, Goniopora, Alveo-pore and Acropora were used in the studies. However, so far there has been no information on the possible practical use of deep-sea (Gorgonacea: Isi-didae) octocorals growing in the environments conditioned by high pressures ( $>80$ atmospheres) and very low temperatures $\left(2-4{ }^{\circ} \mathrm{C}\right)$ [63].

Concerning the coral structure, it is dominated by the presence of calcium carbonate in the form of calcite and aragonite, but there are also organic matter and impurities that disappear by heating the coral material at temperatures above $900{ }^{\circ} \mathrm{C}$. The thermogravimetric curve of the coral shows a weight loss at $680{ }^{\circ} \mathrm{C}$, which occurs due to the decomposition reaction of calcium carbonate present in the coral itself. Synthetic calcium carbonate decomposes to $898{ }^{\circ} \mathrm{C}$. The observed decomposition at $680{ }^{\circ} \mathrm{C}$ may occur due to the substitution of certain ions in the calcite phase, or eutectic reaction caused by the combustion of the organic matter. However, heating the coral material at the temperature of $900{ }^{\circ} \mathrm{C}$ is necessary for the removal of any impurities present, as well as for the decomposition of the carbonate phase [63].

The following types of coral materials have previously been used for biomedical purposes: coral hydroxylapatite and aragonite, coral granules, natural coral fragments, newly developed coral-composite materials and coral powder (coral calcium) [63].

\section{Fishbones}

Fishbones are a material that is economical and easy to obtain. It also contains porous structures of calcium carbonate $\mathrm{CaCO}_{3}$ and calcium phosphate $\mathrm{Ca}_{3}\left(\mathrm{PO}_{4}\right)_{2}$ which have ions that are naturally present in the bone.

Due to its similarity to the bone structure, and due to its composition, crystallinity, pore size and biocompatibility, being a natural material fish bones can be used as an alternative material primarily with bone damage [64].

These materials are obtained from the fish present in various aquatic systems but also from those not used in the food industry. Globally, more than $50 \%$ of fish catches are not produced as a valuable food product, but thrown away in huge quantities reaching more than one million tonnes of unwanted bio-waste. Huge quantities of fish by-products are wasted and create an adverse environmental impact.

Fishbones have recently been used as an inexpensive source for the preparation of natural hydroxyapatites (HAp). However, the properties of the synthesized fish waste HAp and conventional commercial stoichiometric HAp are different. HAp prepared from the fish waste showed a greater biological activity due to the existence 
of essential anions such as $\mathrm{Cl}^{-}$and $\mathrm{F}^{-}$, and cations such as $\mathrm{Mg}^{2+}, \mathrm{Al}^{3+}, \mathrm{Sr}^{2+}, \mathrm{Zn}^{2+}, \mathrm{K}^{+} \mathrm{i} \mathrm{Na}{ }^{+}$, and the appearance of both ions showed a better biomedical application mainly for the rapid bone restoration. The availability of $\mathrm{Na}^{+}$and $\mathrm{Mg}^{2+}$ ions is necessary for the growth and stability of bones and teeth, while their absence or small amount can make bones very fragile and brittle [65].

According to the research, the synthesis of HAp from fish bones is a simple and economical method. Kongsri et al. [67] performed the HAp synthesis from Tilapia nilotica fish bone waste and applied for the selenium adsorption from aqueous solutions. Similarly, Huang et al. [66] have discussed the preparation of HAp from the Oreochromis fish species (tilapia) using an enzymatic hydrolysis method and examined biocompatibility. Abdullah et al. [68] prepared HAp from Black tilapia by a calcination method and confirmed the presence of $\mathrm{Na}^{+}$and $\mathrm{Mg}^{2+}$. Muhammad et al. [69] synthesized HAp from Cyprinidae fish bones with the help of the ionic liquid treatment and examined its biocompatibility. However, the main disadvantage of all the above methods is that it is difficult to control the crystal structure and size of HAp. Therefore, it is important to develop a simple, efficient green method for obtaining biocompatible nanostructured HAp for various biomedical applications [65].

Use of biomaterials

Use of biomaterials in dentistry

Silk has been used in biomedical applications for many years. However, there are only a few applications in dentistry as a material for stitches and the regeneration of the dental tissue. Silk is used for the tissue regeneration alone, or in the combination with other materials as composite materials, and new nanomaterials are developed from silk proteins and silica, which combine the useful properties of the two components.

A material such as hydroxyapatite is an essential component of tooth enamel and dentin because it contributes to the strength and hardness of these tissues. The nucleation of hydroxyapatite and its crystal structure is controlled by organic macromolecules such as osteonectin, phosphoproteins, and dentin matrix protein 1 (DMP-1). DMP-1 plays a major role in controlling the nucleation, growth, and morphology of hydroxyapatite crystals in dentin. Combining spider fibers and DMP-1, a biomimetic approach was used to produce biominerals. For this purpose, spider fiber protein domains and the DMP-1 domain were cloned and the two domains were then used for the orientation and nucleation of hydroxyapatites. This combination resulting from the biomineralization process has great potential in tissue engineering [70].

Seashells are used as a source of exclusion for the production of natural hydroxyapatite. A composite of hydroxyapatite (obtained from a shell) with iron was used as a material for titanium coating by the laser pulse deposition technique for the application of dental implants. [71].

Despite a better understanding of the chemistry of the material and the improvement of its physical properties, the ideal material for all dental applications has not been found yet. Composite alternative materials are promising in aesthetic terms but do not satisfy the mechanical standards of amalgams, and are sensitive to individual dentist techniques.

Usage of biomaterials as an implant (scaffold) for bone formation/healing

Bone, consisting mainly of collagen protein and hydroxyapatite, provides support and the strength for movement. Critical bone defects or serious bone injuries that cannot be regenerated naturally require implant-based interventions. Implants provide mechanical strength to the bone, but also accelerate the growth of natural tissue [72].

The use of silk/clay films as composites in tissue or bone engineering has been extensively studied. Silk film (most commonly obtained from the domestic silkworm Bombyx mori or spider of the Nephila clavipes species) serves to support the biomaterial, while the clay/MMT particles (Montmorillonite) were the source of osteoinductive silicon species.

The silk/clay system has been studied with human mesenchymal stem cells (hMSC) in osteogenic culture to determine the effect on bone outcomes, against silk and silk-sodium silicate (SS) controls. Clay particles provide an osteogenic stimulus for hMSCs and enhance the bone-related ECM (extracellular matrix) production. Clay was chosen as an adjunct to the silk matrix because natural clay minerals represent an osteogenic culture. The silk/clay composite biomaterial gave good results. Biomaterials supported the binding, proliferation and osteogenic differentiation of hMSCs, maintaining high cell viability [73].

A silk/silicate film combination can be used for the same purposes. Spider silk obtained from N. Clavipies is used as a source of silk. Spider silk served as the organic phase controlling the stability of the material. Silk/ silicate biomaterial is suitable for various applications but especially for the formation of previously damaged bones [74].

Mesenchymal stem cells derived from human bone marrow and subjected to osteogenic differentiation were used to evaluate the influence of the silk/silica composite system on osteogenesis. Silicon in these silk films affected the expression of osteogenic genes, with the regulation of several osteogenic markers (alkaline phosphatase, bone sialoprotein, and collagen type I). Calcium-containing deposits have been observed on silicate films treated with silicates, which is a clear indication that bone formation has occurred [74].

The spider silk/calcite composite has led to the development of new applications in the field of bone implants and artificial dentures. Characteristics of a good bone implant are biocompatibility, bone-bonding and strength, while artificial dentures must have characteristics such as the strength necessary for holding (enduring body 
weight) and the flexibility in movement (allowing easier movement). Calcium carbonate on spider silk mattress will provide bone support and improve the alternative offered to a patient who has had an amputation or has bone defects that need to be alleviated [75].

In the orthopedic field, hydroxyapatite (HAp) nanocrystals are sintered and have improved disinfection because of the high surface area. The high surface area can also increase the fracture toughness and mechanical strength of HAp nanocrystals. Compared to other constructs, nano HAp showed better bioactivity compared to coarse crystals that extend their applications in tissue engineered implants. Nano HAp has high bioresorption properties and similar crystallographic and chemical characteristics as natural apatite found in the bone. Nano HAp-containing composites induced both osteogenesis and angiogenesis by stimulating osteoblast proliferation, adhesion, and differentiation; therefore, these composites are essential for bone tissue applications. The silk fiber protein extracted from B.mori alone or in combination with $\mathrm{CaP}$ (calcium phosphates) is used to engineer a bone tissue. Nano HAp/SF powders (Shown in Figure 6.) were synthesized using the coprecipitation method and added to the SF (Silk fibroin) solution to produce the nHAp/SF composite material. These composites showed improved pressure properties. Good compression properties were due to uniform dispersion of nHAp/SF in SF solution, a high surface area of the needle nHAp/SF powder and a good molecular interaction between SF molecules in the structure of the $\mathrm{nHAp} / \mathrm{SF}$ powder and SF matrix. Good interface interactions between nHAp/SF powder and SF matrix promoted cell proliferation, binding, and differentiation [76].

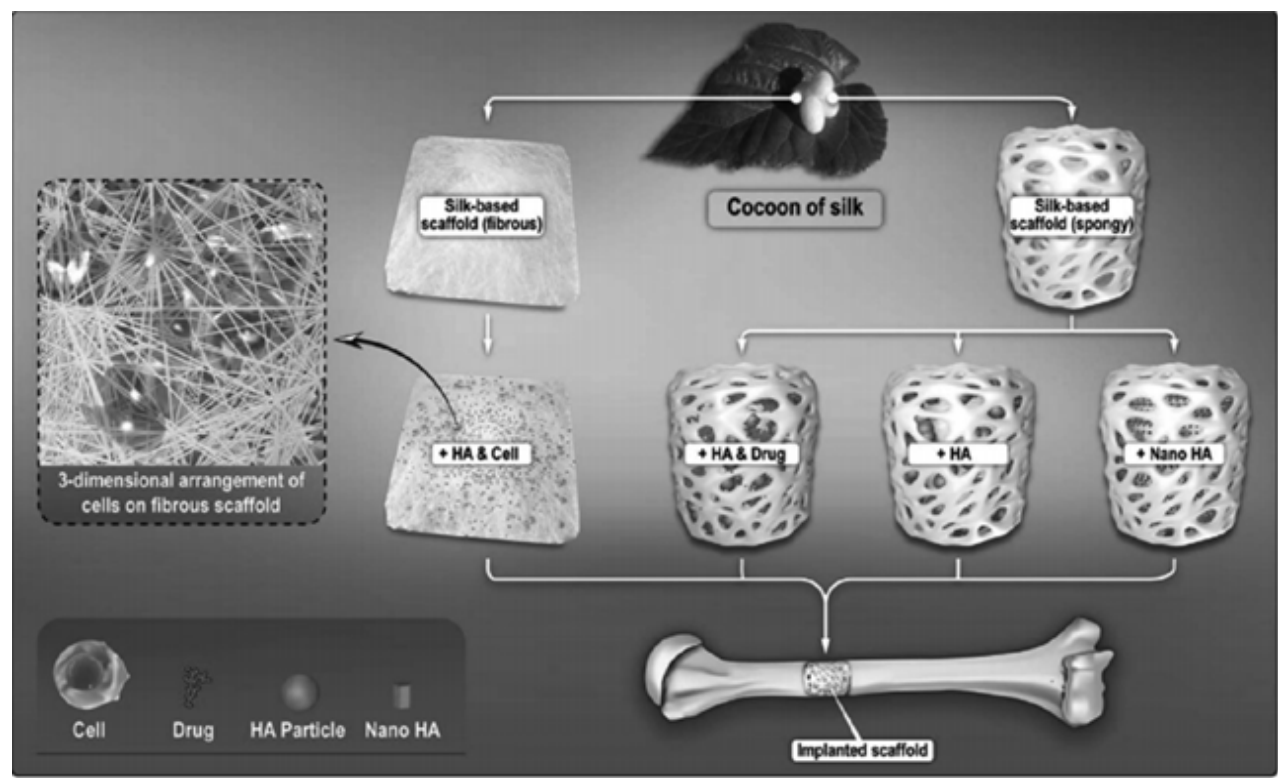

Figure 6. Silk/hydroxyapatite (SF-HAp) composites used in bone tissue engineering [76].

Strontium $(\mathrm{Sr})$ is a natural element that can be part of the bones because of the similarity in physical and chemical structure with $\mathrm{Ca}$ contained in them. The incorporation of $\mathrm{Sr}$ into the bones shows a better result in the treatment of osteoporosis. The addition of $\mathrm{Sr}$ to the HAp crystal leads to a greater distance of $\mathrm{Sr}-\mathrm{OH}$ than $\mathrm{Ca}-\mathrm{OH}$ due to the larger ion diameter of $\mathrm{Sr}$, which further leads to a change in the lattice parameters of apatite. The lattice parameters of Sr-substituted HAp increase with increasing the $\mathrm{Sr}$ concentration. The addition of $\mathrm{Sr}^{2+}$ may increase the solubility of the synthesized HAp, leading to better alkaline activity of osteoblasts and the collagen formation in the physiochemical system. An in vitro study showed that Sr-substituted HAp powder promotes osteoblast differentiation and decreases the osteoclast number and activity. Sr-substituted HAp was synthesized from Mercenaria hard shells by the hydrothermal process. The effect of Sr substitution on the mechanical behavior and in vitro cytotoxicity using a mouse osteoblast cell line (MC3T3) was performed to evaluate the potential of biomedical application materials [77].
Sivakumar et al. [78] have shown the possibility of converting the coral found on the Indian coast into a product that is extremely rich in hydroxyapatite. However, apatite obtained under the experimental conditions used in this study is in powder form. Powdered hydroxyapatite can be used to form bone filling composites as well as for osteogenic purposes. It can also be used for plasma sprays to coat bioimplants.

Porous hydroxyapatite implants can be biogenic powder of hydroxyapatite obtained from the fishbone (Thickness Perch) and the polymer sponge obtained by the heat treatment at $1250{ }^{\circ} \mathrm{C}$ for $3 \mathrm{~h}$. Calcined fishbone maintains the microstructural characteristics of raw fishbones. Despite the high porosity of the prepared implants, they have mechanical properties sufficient for the application to the bone material. XRD examination of a calcium phosphate layer deposited on the implant surface after the immersion into SBF (simulated body fluid) revealed a pure hydroxyapatite phase identical to the standard one [79]. 
Use of biomaterials as antimicrobial agents

Loss of the skin tissue when exposed to fire leaves a wound/burn susceptible to dehydration and infection. In serious injuries, burns can take up about $70 \%$ of the patient's skin, which is why deaths most often result from secondary infections. To protect the patient's body from invading microorganisms at the wound site, wound dressings are used to cover the wound as the skin regenerates [80].

Wound dressings are usually made of naturally-derived and biocompatible materials such as silk, specifically. It is very often silk obtained from silkworm (Bombyx mori), although spider silk is also used. These biomaterials often incorporate nanoparticles that have antimicrobial properties to destroy micro-organisms as effectively as possible, and prevent them from developing. A particle having such properties is silver in the form of $\mathrm{Ag}^{+}$and $\mathrm{Ag}^{0}$. Silver is obtained from compounds such as silver nitrate, silver sulfate, silver sulfadiazine [80].

Based on many studies and dealing with the fabrication and the evaluation of silk, wound dressings with the incorporation of silver nanoparticles in low concentrations have shown that this combination is particularly effective against the following microorganisms: S. Aureus, P. Aeruginosa and E. Coli (Shown in Figure 7.)[ 80].
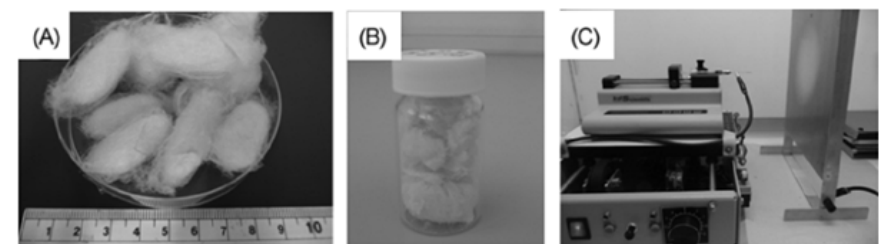

Figure 7. This image shows the transformation of silk fibroin from (A) unprocessed B. mori silkworm cocoon to (B) extracted, lyophilized silk fibroin and (C) final, electrospun silk fibroin mat [80].

Due to advances in nanotechnology, many nanomaterials with unique functions and structures have been synthesized. The combination of multifunctional nanomaterials and silk is considered to be one of the most effective strategies for obtaining silk fabrics with improved properties. Cerium oxide $\left(\mathrm{CeO}_{2}\right)$ nanoparticles have received considerable attention due to their unique applications as catalyst or catalyst support, superconducting buffer layer, oxygen storage material, fuel cell electrolytes, and UV absorbers. The excellent antibacterial activity of $\mathrm{CeO}_{2}$ nanoparticles against Gram-negative and Gram-positive bacteria has been previously demonstrated. The benefits make the $\mathrm{CeO}_{2}$ nanoparticle a good candidate to enable and enhance the use of silk fibers as antibacterial agents and for UV protection [81].

The antibacterial activity of the composite $\mathrm{CeO}_{2} /$ silk fiber nanoparticles (obtained from the Bombyx mori silkworm) against Escherichia coli (E. coli), Staphylococcus aureus (S. aureus), Pseudomonas aeruginosa (P. aeruginosa) and Bacillus subtilis (B. subtilis) as microbial model was considered to be extremely good, which is why this composite has found the application in making wound dressings for wounds (Shown in Figure 8.) [81].

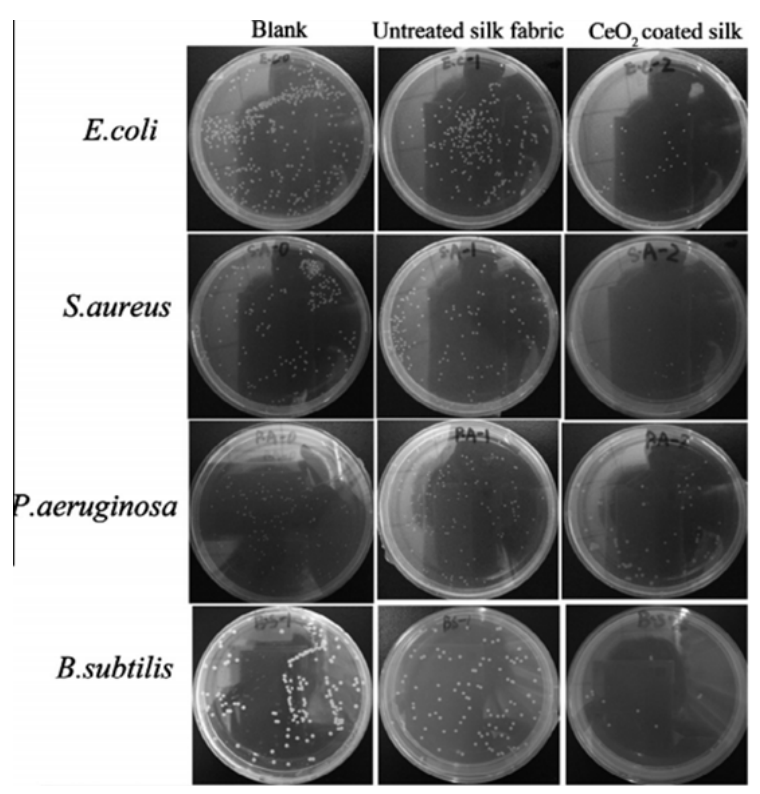

Figure 8. The antimicrobial activity of the $\mathrm{CeO}_{2}$ /silk composite obtained from Bombyx mori [81].

The combination of silk (also obtained from the silkworm Bombyx mori) and zinc oxide $(\mathrm{ZnO})$ can be used for the same purposes. ZnO nanoparticles are considered to be non-toxic and biocompatible and are therefore frequently used. $\mathrm{ZnO}$ in the combination with silk fibers has remarkable properties, but particularly pronounced antimicrobials that are used to suppress bacteria of the species Staphylococcus aureus, Escherichia coli, and Streptococcus agalactiae (Shown in Figure 9.) [82].

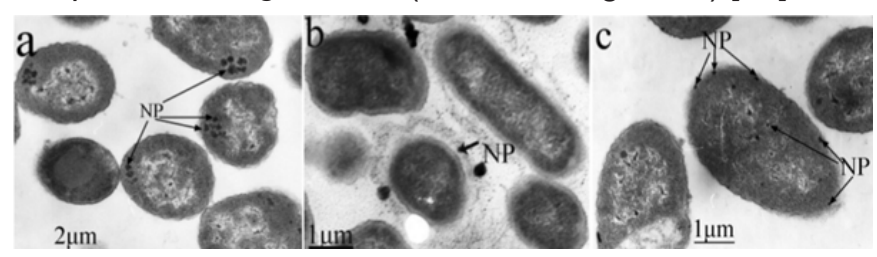

Figure 9. TEM images of thin sections of bacteria with the biomineralized sample (0.003 M); (a) Streptococcus agalactiae, (b) Escherichia coli, and (c) Staphylococcus aureus, in which the nanoparticle (NP) is $\mathrm{ZnO}$ [82].

Natural shell-based materials can also be used for antimicrobial purposes. Aras et al. [83] prepared the material based on $\mathrm{CeO}_{2}$ /Aloe vera with the particles in the form of a powder of the obtained shell by a simple method, and confirmed their crystalline nature. The applications of the materials towards the inhibition of pathogenic microorganisms were its advantage. Interestingly, the prepared samples show a promising antimicrobial activity against pathogenic microorganisms such as Staphylococcus aureus and Pseudomonas fluorescence with a comparable activity to standard commercially available antibiotics (Shown in Figure 10.). It is predicted that the shell structure and phytochemical contents such as alkaloids, flavonoids, terpenoids and other phenolic constituents present in A. vera plants could enhance its bacterial activities [83]. 


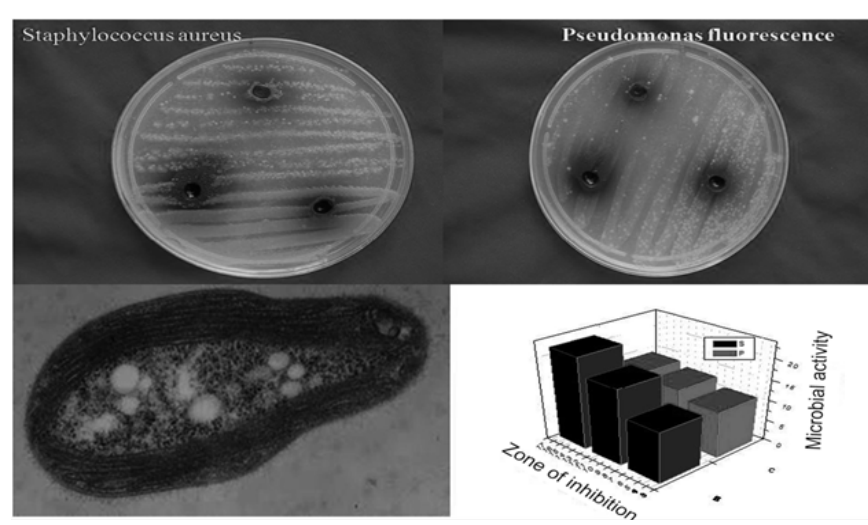

Figure 10. The antimicrobial activity variation and its graph $\mathrm{CeO}_{2} / 3 \%$ A. vera/Seashell (CAS) [83].

Use of biomaterials in order to dispense medication

Compounds such as hydrotalcite (HTlc) or layered double hydroxide (LDHs) are an important layered matrix that can be represented by the general formula $\left[\mathrm{M}(\mathrm{II})_{1-\mathrm{x}} \mathrm{M}(\mathrm{III})_{\mathrm{x}}(\mathrm{OH})_{2}\right]^{\mathrm{x}}\left[\mathrm{A}_{\mathrm{x} / \mathrm{n}}^{\mathrm{n}}\right] \mathrm{mH}_{2} \mathrm{O}$ where $\mathrm{M}(\mathrm{II})$ is a divalent cation such as $\mathrm{Mg}, \mathrm{Ni}, \mathrm{Zn}, \mathrm{Cu}$, or $\mathrm{Co}, \mathrm{M}$ (III) is a trivalent cation such as $\mathrm{Al}, \mathrm{Cr}, \mathrm{Fe}$, or $\mathrm{Ga}, \mathrm{A}^{\mathrm{n}-}$ is an anion having charge $n$. Most commonly as divalent metal is used $\mathrm{Zn}$ and as trivalent Al. HTlc is the only example of layered solids with positively charged layers and interchangeable anions in order to maintain charge neutrality. Intermediate anions can be replaced by other inorganic, metal-organic or organic anions and biomolecules [1].

Due to their low toxicity and good biocompatibility, HTIc is used in biological and pharmaceutical fields for the controlled storage and release of active species intercalated in layered materials. Due to their incorporated layered density and chemical composition, HTIc can be used in nanocomposites for drug release. And most often, these composites are the combination of silk and HTIc [1].

Silk also has exceptionally good characteristics: it is biocompatible, non-toxic and promotes the action of HTIc in order to release medicines.

Use of biomaterials in regenerative neuron medicine

Single-Walled Carbon Nanotubes (SWCNTs) represent the most interesting class among conductive nanomaterials for biomedical applications. They have unique physical and chemical properties which allow the development of high- capacity, low-resistance nanostructured electrodes that are potentially useful for connecting cells and modulating the cell activity, i.e. for neurological prosthetics. In this context, scientists generated a conductive nanostructured (n) SF(silk fibroin)-SWCNTs film by using the same fabrication method applied in order to produce three-dimensional (3D) ordered structures of interconnected submicrometric pores of SWCNTs. Structural, electrical, conformational, mechanical properties and biocompatibility with primary neural cells of primary gornoling (DRG) of SF-SWCNTs nanocomposite film were investigated [84].
The biocompatible nanocomposite can potentially be used to promote and guide neuronal outgrowth, as well as to stimulate the functional recovery of injured neurons representing a key tool in neuronal regenerative medicine and nerve repair [84].

\section{Conclusion}

Biomaterials are a huge group of materials that have exceptional features such as biocompatibility, inertness, and many others, and because of these characteristics, these materials are widely used. In recent years, scientists have been attracted to natural materials like spider silk or silkworm, but also materials such as shells, corals, fish bones and eggshells. Nowadays, with the development of technology, (nano) composite materials have been extensively tested based on the precursors mentioned above. They have exceptions to the feature and are applied in many branches such as bone and tissue engineering, making wound dressings and other nonsurgical material, a drug delivery systems, the skeletal tissue development, and many others.

\section{Acknowledgement}

The authors wish to thank to the Ministry of Education, Science and Technological Development (project TR 34008) of the Republic of Serbia for the financial support.

\section{References}

[1] V. Ambrogi, V. Ciarnelli, M. Nocchetti, L. Perioli, C. Rossi, Effect of hydrotalcite-like compounds on the aqueous solubility of some poorly water-soluble drugs, Journal of the Pharmceutical Science 73 (2009) 285-91.

[2] D. Rakovića i D. Uskokovića: Biomaterijali, ITN-SANU, 2010.

[3] Teddei P, Tinti A, Fini G., Vibrational spectroscopy of polymeric biomaterials, Journal of Raman Spectroscopy 32 (2001) 619-629.

[4] Altman G H, Diaz F, Jakuba C, Calabro T, Horan RL, Chen J, Lu H. Richmond J, Kaplam DL. Silk-based biomaterials, Biomaterials 24 (2003) 401-416.

[5] Gerritsen V,The tiptoe of an airbus, Protein Spotlight Swiss Prot, 24 (2002) 1-2.

[6] Gosline J, Guerette P, Ortlepp C, Savage K, The mechanical design of spider silks: from fibroin sequence to mechanical function, Journal of Experimental Biology, 202 (1999) 3295-3303.

[7] Vollrath F, Barth P, Basedow A, Engstrom W, List H, Local tolerance to spider silks and protein polymers in vivo, In Vivo 16 (2002) 229-234.

[8] A. Sponner, W. Vater, S. Monajembashi, E. Unger, F. Grosse, K. Weisshart, Composition and Hierarchial Organisation of a Spider Silk, Plos One, 10 (2007) e998

[9] Cameron G. Copeland- Production of Synthetic Spider Silk Fibers, Thessis, Department of Biological Engineering, Utah State University, 2016

[10] A. Nova, S. Keten, N.M. Pugno, A. Redaelli, M.J. Buehler, Molecular and nanostructural mechanisms of deformation, strength and toughness of spider silk fibrils, Nano Letter, 
10 (2010) 2626-2634.

[11] Aprhisiart A, Vollrath F, Design-features of the orb web of the spider, Araneus-diadematus, Behavioral Ecology, 5 (1994) 280-287,

[12] Hinman M, Lewis $R$, Isolation of a clone encoding a second dragline silk fibroin Nephila clavipes dragline silk is a two protein fiber, Journal of Biological Chemistry, 267 (1992) 19320-19324.

[13] Ayoub N, Garb J, Tinghitella R, Collin M, Hayashi C, Blueprint for a high-performance biomaterial: full-length spider dragline silk genes, Plos One 2 (2007) e514

[14] Andersen S, Amino acid composition of spider silks, Comparative Biochemistry and Physiology, 35 (1970) 705-711.

[15] Kummerlen J, Van Beek J, Vollrath F, Meier B, Local structure in spider dragline silk investigated by twodimensional spindiffusion nuclear magnetic resonance, Macromoleculs, 29 (2006) 2920-2928.

[16] Hayashi C, Shipley N, Lewis R, Hypotheses that correlate the sequence, structure, and mechanical properties of spider silk proteins, International Journal of Biological Macromoleculs 24 (1999) 271-275.

[17] Askarieh G, Hedhammar M, Nordling K, Saenz A, Casals C, Rising A, Johansson J, Knight S, Self-assembly of spider silk proteins is controlled by a $\mathrm{pH}$-sensitive relay, Nature 465 (2010) 236-239.

[18] Eisoldt L, Smith A, Scheibel T, Decoding the secrets of spider silk, Materials Today 14 (2011) 80-86.

[19] Hagn F, Eisoldt L, Hardy J, Vendrely C, Coles M, Scheibel $\mathrm{T}$, Kessler $\mathrm{H}, \mathrm{A}$ highly conserved spider silk domain acts as a molecular switch that controls fibre assembly, Nature 465 (2010) 239-242.

[20] Hagn F, Thamm C, Scheibel T, Kessler H, pH-Dependent dimerization and salt-dependent stabilization of the $\mathrm{N}$-terminal domain of spider dragline silk-implication for fibre formation-Angewandte Chemie International Edition 50 (2011) 310-313.

[21] W.J. Stadelman, Egg and egg products, F.J. Francis (Ed.), Encyclopedia of Food Science and Technology, John Wiley \& Sons, New York, 2000, pp. 593-599.

[22] Zhou J, Wang S, Nie F, Feng L, Zhu G, Jiang L, Elaborate architecture of the hierarchical hen's eggshell, Nano Research, 4 (2010) 171-179.

[23] Rodriguez-Navarro A, Yebra A, Nys Y, Jimenez-Lopez J, Garcia-Ruiz J, Analysis of avian eggshell microstructure using X-ray area detectors, European Journal of Minerogy, 19 (2007) 391-398

[24] Guru P, Dash S, Sorption on eggshell waste a review on ultrastructure, biomineralization and other applications, Advances in Colloid Interface Science, 209 (2014) 49-67

[25] Kingori A, A review of the uses of poultry eggshells and shell membranes, International Journal Poultry Science, 10 (2011) 908-912.

[26] Tacon A, Utilisation of chick hatchery waste: the nutritional characteristics of day-old chicks and eggshells, Agricultural Wastes, 4 (1982) 335-343.

[27] Park H, Jeong S, Yang J, Kim B, Lee S, Removal of heavy metals using waste eggshell, Journal Environmental Science, 19 (2007) 1436-1441.

[28] Flores-Cano J, Leyva-Ramos R, Mendoza-Barron J, Guerrero-Coronado R, Aragon-Pina A, Labrada-Delgado $\mathrm{G}$, Sorption mechanism of $\mathrm{Cd}(\mathrm{II})$ from water solution onto chicken eggshell, Applied Surface Science, 276 (2013) 682-690.
[29] Podstawczyk D, Witek-Krowiak A, Chojnacka K Sadowski Z, Biosorption of malachite green by eggshells: mechanism identification and process optimization, Bioresource Technology, 160 (2014) 161-165

[30] Gergely G, Wéber F, Lukács I, Tóth A, Horváth Z, Mihály $\mathrm{J}$, Balázsi $\mathrm{C}$, Preparation and characterization of hydroxyapatite from eggshell, Ceramics International, 36 (2010) 803-806.

[31] Mohammadi M, Lahijani P, Mohamed A, Refractory dopant-incorporated $\mathrm{CaO}$ from waste eggshell as sustainable sorbent for $\mathrm{CO}_{2}$ capture: experimental and kinetic studies, Chemical Engineering Journal, 243 (2014) 455-464.

[32] Toro P, Quijada R, M. Yazdani-Pedram M, Arias J, Eggshell, a new bio-filler for polypropylene composites, Material Letters, 61 (2007) 4347-4350.

[33] Ghani S, Young H, Conductive polymer based on polyaniline-eggshell powder (PANI-ESP) composites, Journal of Physical Science, 21 (2010) 81-97.

[34] Mosaddegh E, Ultrasonic-assisted preparation of nano eggshell powder: a novel catalyst in green and high efficient synthesis of 2-amino chromenes, Ultrasonics Sonochemistry, 20 (2013) 1436-1441.

[35] Mijan M, Kim D, Kwak H, Physicochemical properties of nanopowdered eggshell, International Journal of Food Science and Technology, 49 (2013) 1751-1757.

[36] Baláž M, Eggshell membrane biomaterial as a platform for the applications in materials science, Acta Biomaterialia, 10 (2014) 3827-3843.

[37] Baláž P, Calka A, Zorkovská A, Baláž M, Processing of eggshell biomaterial by electrical discharge assisted mechanical milling (EDAMM) and high energy milling (HEM) techniques, Materials and Manufacturing Processes, 28 (2013) 343-347.

[38] Baláž $M$, Baláž $P$, Bujnáková $Z$, Pap Z, Kupka $D$, Zorkovská A, Mechanochemical dechlorination of PVC by utilizing eggshell waste, Acta Physia Polonica A, 126 (2014) 884-887.

[39] Schrader R, Hoffman B, Enantiotropic transformation of calcite-aragonite by mechanical forces, Zeitschrift Chemie, 6 (1966) 388-389.

[40] Lin I, Somasundaran P, Alterations in properties of samples during their preparation by grinding, Powder TechnolOGY, 6 (1972) 171-179.

[41] Martinez G, Morales J, Minura G, Grinding-induced structural transformations in $\mathrm{CaCO}_{3}$, Journal of Colloid and Interface Science, 81 (1981) 500-510.

[42] Garcia F, Le Bolay N, Frances C, Changes of surface and volume properties of calcite during a batch wet grinding process, Chemical Engineering Journal, 85 (2002) 177187.

[43] Lin Y, Singer P, Inhibition of calcite crystal growth by polyphosphates, Water Research, 39 (2005) 4835-4843.

[44] Baláž M, Eggshell membrane biomaterial as a platform for applications in materials science, Acta Biomaterialia, 10 (2014) 3827-3843.

[45] Fleischli D, Dietiker M, Borgia C, Spolenak R, "The influence of internal length scales on mechanical properties in natural nanocomposites: A comparative study on inner layers of sea shells", Acta Biomaterialia, 4(2008) 1694-1706.

[46] Barthelat F, Rabiei R, Toughness amplification in Natural composites, Journal of the mechanics and physics of solids, 59 (2011) 829-840. 
[47] Chateigner D, Hedegaard C, Wenk H, Mollusc shell microstructures and crystallographic textures, Journal of Structural Geology, 22 (2000) 1723-1735.

[48] Barthelat F, On the mechanics of the mother pearl: $A$ key feature in material hierarchical structure, Journal of mechanics and physics of solids, 55 (2007) 306-337.

[49] Falade F, 1992, The use of palm kernel shells as coarse aggregate in concrete, Journal of Housing Science, 16 (1992) 213-219.

[50] Kaplan D, Mollusc shell structures: Novel design strategies for synthetic materials, Current opinion in solid state and materials science, 3 (1998) 232-236.

[51] Pujala R, Artificial Nacre Nanocomposites for Advanced Applications, Nanomedicine and Nanotechnology Journal, 2 (2018) 117

[52] Hamli H, Idris M H, Abu Hena M, Wong S, Taxonomic Study of Edible Bivalve from Selected Division of Sarawak, International Journal of Zoological Reearch, 8 (2012) 5258.

[53] Yan L, Schöne B, Li S, Yan Y, Shells of Paphia undulata (Bivalvia) from the South China Sea as potential proxy archives of the East Asian summer monsoon: a sclerochronological calibration study, The Oceanographic Society of Japan and Springer Japan, 70 (2013) 35-44.

[54] Boey P, Maniam G, Hamid S, Ali D, Utilization of waste cockle shell (Anadara granosa) in biodiesel production from palm olein: Optimization using response surface methodology, Fuel, 90 (2011) 2353-2358.

[55] Wu X, Xiao S, Li X, Li L, Shi W, Yu Z, Evolution of the tRNA gene family in mitochondrial genomes of five Meretrix clams (Bivalvia, Veneridae), Gene, 533 (2014) 439-446.

[56] Muthusamy K, Sabri N, Cockle Shell: A Potential Partial Coarse Aggregate Replacement in Concrete, International Journal of Science, Environment and Technology, 1 (2012) 260-267.

[57] Saharudin S, Shariffuddin J, Nordin N, Biocomposites from (Anadara granosa) shells waste for bone material applications, IOP Conf. Series: Materials Science and Engineering, 257 (2017) 012061.

[58] Jones M, Wang L, Abeynaike A, Patterson D, Utilisation of waste material for environmental applications: calcination of mussel shells for waste water treatment, Advances in Applied Ceramics, 110 (2013) 280-286.

[59] Mohamed M, Yusup S, Maitra S, Decomposition study of calcium carbonate in cockle shell, Journal of Engineering Science and Technology, 7 (2012) 1-10.

[60] Shariffuddin J, Jones M, Patterson D, Hydroxyapatite derived from waste mussel shells for the photocatalytic degradation of a model azo dye wastewater, Chemical Engineering Research \& Design, 91 (2013) 1693-1704.

[61] Khiri M Z, Matori K A, Zainuddin N, Abdullah C A, Alassan Z N, Baharuddin N, The usability of ark clam shell (Anadara granosa) as calcium precursor to produce hydroxyapatite nanoparticle via wet chemical precipitate method in various sintering temperature, Springerplus, 5 (2016) 1206-1221.

[62] Sanosh K, Chu M-C, Balakrishnan A, Kim T, Cho S-J, Preparation and characterization of nano-hydroxyapatite powder using sol-gel technique, Bulletin of Materials Science, 32 (2009) 465-470.

[63] Sivakumar M, Sampath Kumart T, Shantha K, Panduranga Rao K, Development of hydroxyapatite derived from Indian coral, Biomateriols 17 (1996) 1709-1714

[64] Aksakal B, Demirel M, Synthesis and fabrication of novel cuttlefi sh (Sepia officinalis) backbone biografts for biomedical applications, Ceramics International, 41 (2015) 4531- 4537.

[65] Sathiskumar S, Vanaraj S, Sabarinathan D, Bharath S, Sivarasan G, Arulmani S, Preethi K, Ponnusamy V, Green synthesis of biocompatible nanostructured hydroxyapatite from Cirrhinus mrigala fish scale - A biowaste to biomaterial, Ceramics International, 45 (2019) 7804-7810.

[66] Huang Y, Hsiao P, Chai H, Hydroxyapatite extracted from fish scale: effects on MG63 osteoblast-like cells, Ceramics International, 37 (2011) $1825-1831$.

[67] Kongsri S, Janpradit K, Buapa K, Techawongstien S, Chanthai S, Nanocrystalline hydroxyapatite from fish scale waste: preparation, characterization and application for selenium adsorption in aqueous solution, Chemical Engineering Journal, 215 (2013) 522-532.

[68] Fara A, Abdullah $\mathrm{H}$, Characterization of derived natural hydroxyapatite (HAp) obtained from different types of tilapia fish bones and scales, Malaysian Journal of Microscopy, 10 (2014) 34-40.

[69] Muhammad N, Gao Y, Iqbal F, Ahmad P, Ge R, Nishan U, Rahim A, Gonfa G, Ullah Z, Extraction of biocompatible hydroxyapatite from fish scales using novel approach of ionic liquid pretreatment, Separation and Purification Technology, 161 (2016) $129-135$.

[70] Zafar M, Al-Samadani K. Potential use of natural silk for bio-dental applications, Journal of Taibah University Medical Science, 9 (2014) 171-177.

[71] Trinkunaite-Felsen J, Prichodko A, Semasko $M$, Skaudzius R, Beganskiene A, Kareiva A, Synthesis and characterization of iron-doped/substituted calcium hydroxyapatite from seashells Macoma balthica (L.), Advanced Powder Technology, 26 (2015) 1287-1293.

[72] Kapoor S, Kundu S, Silk protein-based hydrogels: Promising advanced materials for biomedical applications, Acta Biomaterialia, 31( 2016) 17-32.

[73] Mieszawska A, Liamas J, Vaiana C, Kadakia M, Naik $R$, Kaplan D, Clay enriched silk biomaterials for bone formation, Acta Biomaterialia, 7 (2011) 3036-3041.

[74] Tokareva O, Jacobsen M, Buehler M, Wong J, Kaplan D, Structure-function-property-design interplay in biopolymers: Spider silk, Acta Biomaterialia, 10 (2014) 3036-3041.

[75] Mehta N, Hede S, Spider Silk Calcite Composite, Hypothesis Journal, 3 (2011) 21-25.

[76] Farokhia M, Mottaghitalab F, Samanic S, Shokrgozara M, Kundud S, Reisd R, Fatahie J, Kaplan D, Silk fibroin/ hydroxyapatite composites for bone tissue engineering, Biotechnology Advances, 36 (2018) 68-91.

[77] Pal A, Nasker P, Paul P, Chowdhury A, Sinha A, Das M, Strontium doped hydroxyapatite from Mercenaria clam shells: Synthesis,mechanical and bioactivity study, Jurnal of the Mechanical Behavior Of Biomedical materials, 90 (2019) 328-336.

[78] Sivakumar M, Sampath Kumart T, Shantha K, Panduranga Rao K, Development of hydroxyapatite derived fkom Indian coral, Biomaterials, 17 (1996) 1709-1714.

[79] Naga S, El-Maghraby H, Mahmoud E, Talaat M, Ibrhim A, Preparation and characterization of highly porous ceramic scaffolds based on thermally treated fish bone, Ceramics International, 41 (2015) 15010-15016.

[80] Uttayarat P, Jetawattana S, Suwanmala P, Eamsiri $\mathrm{J}$, Tangthong T, Pongpat S, Antimicrobial Electrospun Silk Fibroin Mats with Silver Nano particles for Wound 
Dressing Applications, Fibers and Polymers, 13 (2012) 999-1006.

[81] Lu Z, Mao C, Meng M, Liu S, Tian Y, Yu L, Sun B, Li $C$, Fabrication of $\mathrm{CeO}_{2}$ nanoparticle-modified silk for UV protection and antibacterial applications, Journal of Colloid and Interface Science, 435 (2014) 8-14.

[82] Yan D, Yin G, Huang Z, Yang M, Liao X, Kang Y, Yao Y, Hao B, Han D, Characterization and Bacterial Response of Zinc Oxide Particles Prepared by a Biomineralization Process, Journal of Physical Chemistry B, 113 (2009) 6047-6053.

[83] Arasu M, Thirumamagal R, Srinivasan M, Al-Dhabi N, Ayeshamariam A, Saravana Kumar D, Punithavelan N, Jayachandran M, Green chemical approach towards the synthesis of $\mathrm{CeO}_{2}$ doped with seashell and its bacterial applications intermediated with fruit extracts, Journal of Photochemistry \& Photobiology B: Biology, 173 (2017) 50-60.

[84] Dionigi C, Posati T, Benfenati V, Sagnella A, Bonetti S, Ruani G, Dinelli F, Padeletti G, Zamboni R, Muccini M, A nanostructured conductive bio-composite of silk fibroinsingle walled carbon nanotubes, Journal of Material Chemistry B, 2 (2014) 1424-31.

[85] www.google.com/images/spidersilkinnature

Izvod

\section{RAZLIČITE VRSTE BIOMATERIJA:STRUKTURA I PRIMENA: KRATAK PREGLEDNI RAD}

Miljana Z. Rubežić, Aleksandra B. Krstić, Hristina Z. Stanković, Radomir B. Ljupković, Marjan S. Ranđelović, Aleksandra R. Zarubica

Univerzitet u Nišu, Prirodno-matematički fakultet, Niš, Srbija

Biomaterijali se karakterišu kao bilo koji materijal prirodnog ili sintetičkog porekla koji dolazi u kontakt sa tkivom, krvlju ili biološkim tečnostima pacijenta i koji se zbog izuzetnih strukturalnih karakteristika ali i potencijalne primene u mnogim granama industrije i medicine ( protetičnoj, dijagnostičkoj, terapijskoj ili skladišnoj primeni,itd.) koriste u cilju unapređenja života pacijenta. Od naročite važnosti su pre svega biomaterijali koji mogu se naći svuda u prirodi, kako na kopnu tako i u vodi. To su materijali na bazi paukove mreže, svile svilene bube, korala, školjki, kostiju riba kao i ljuski jajeta. Struktura ovih materijala je izuzetno zanimljiva zbog karakteristika kao što su izuzetne fizičko-hemijske, mehaničke osobine koje dalje omogućavaju primenu u različitim granama medicine kao što su ortopedija, neurologija, stomatologija, tkivni inžinjering. Primena se bazira na upotrebi ovih materijala u obliku različitih implanta, nosača za biomolekule, sredstava za zarastanje rana, antimiktrobnih sredstava, plombi za zube i to zahvaljujući činjenici da imaju izuzetno dug vek trajanja i da postoji minimalna potreba za zamenom /popravkom.
(PREGLEDNI RAD)

UDK 66.017/.018:615.46

Ključne reči: korali, ljuske jajeta, školjke, svilena buba, paukova mreža 